\title{
TU/e EmonOWEN

\section{Adjustment of corporate real estate during a period of significant business change}

\section{Citation for published version (APA):}

Cooke, H., Appel - Meulenbroek, H. A. J. A., \& Arentze, T. A. (2019). Adjustment of corporate real estate during a period of significant business change. International Journal of Strategic Property Management, 23(3), 171-186. https://doi.org/10.3846/ijspm.2019.7954

\section{Document license:}

CC BY

DOI:

10.3846/ijspm.2019.7954

Document status and date:

Published: 18/02/2019

\section{Document Version:}

Accepted manuscript including changes made at the peer-review stage

\section{Please check the document version of this publication:}

- A submitted manuscript is the version of the article upon submission and before peer-review. There can be important differences between the submitted version and the official published version of record. People interested in the research are advised to contact the author for the final version of the publication, or visit the $\mathrm{DOI}$ to the publisher's website.

- The final author version and the galley proof are versions of the publication after peer review.

- The final published version features the final layout of the paper including the volume, issue and page numbers.

Link to publication

\section{General rights}

Copyright and moral rights for the publications made accessible in the public portal are retained by the authors and/or other copyright owners and it is a condition of accessing publications that users recognise and abide by the legal requirements associated with these rights.

- Users may download and print one copy of any publication from the public portal for the purpose of private study or research.

- You may not further distribute the material or use it for any profit-making activity or commercial gain

- You may freely distribute the URL identifying the publication in the public portal.

If the publication is distributed under the terms of Article 25fa of the Dutch Copyright Act, indicated by the "Taverne" license above, please follow below link for the End User Agreement:

www.tue.nl/taverne

Take down policy

If you believe that this document breaches copyright please contact us at:

openaccess@tue.nl

providing details and we will investigate your claim. 


\title{
ADJUSTMENT OF CORPORATE REAL ESTATE DURING A PERIOD OF SIGNIFICANT BUSINESS CHANGE
}

\author{
Received 3 September 2017; accepted 6 June 2018
}

Howard Cooke

Department of the Built Environment Eindhoven University of Technology, Eindhoven Netherlands

Rianne Appel-Meulenbroek

Department of the Built Environment Eindhoven University of Technology, Eindhoven Netherlands

Theo Arentze

Department of the Built Environment Eindhoven University of Technology, Eindhoven Netherlands

Corresponding author: Howard Cooke 69 Derwent Drive, Maidenhead, SL66LE.UK.Email: hc@core-consult.co.uk

\begin{abstract}
This paper seeks to understand whether the alignment process between business strategy and Corporate Real Estate (CRE) between 2007 and 2014 was dynamic. It investigated the financial data of 230 UK companies by means of a distributed time lag auto-regression model. The results show an increased commitment to CRE suggesting a reduced ability to dynamically align the portfolio. Evidence is found that CRE adjusts as turnover, profitability and employment numbers alter. However, measures of efficiency, effectiveness and productivity are not improving. The new business strategies of transient competitive advantage and blue oceans strategy require flexible resources, which require CRE to be capable of dynamic alignment. This study shows such flexibility does not yet exist in practice. Current theories of alignment should be reconsidered in light of the changing business environment. Without a dynamic alignment capability of CRE a company's financial performance will be impaired.
\end{abstract}

Keywords: Corporate real estate; CRE; competitive advantage; business strategy; dynamic alignment; change.

\section{Short biographical notes on all contributors:}

Howard Cooke is a PhD student at Eindhoven University of Technology and Director of CORE Consult which specialises specialising in all aspects of corporate real estate. His work includes acquisitions, asset management, disposals, restructuring, litigation management, and portfolio management strategies. A major focus of his work has been in mitigating surplus lease liabilities.

Rianne Appel-Meulenbroek is an Assistant Professor of Corporate Real Estate Management and workplace at the Eindhoven University of Technology. Her research focuses on the way building design can support an organization, through productivity of employees, innovation, knowledge sharing etc. and how this is best managed.

Theo Arentze is Professor in the Real Estate Management and Development group in the department of the Built Environment of the Eindhoven University of Technology. His research focuses on the analysis and modelling of spatial choice behaviour of users in the built environment and the application of the models for large-scale simulation and decision support.

\section{Introduction}

The direction a business takes is, to a large extent, determined by its strategy. Strategic concepts exist for a long time, as techniques taught in business school stay with a manager throughout their professional life. Sustained competitive advantage (Porter, 1985) is a strategic concept that continues to have a long-lasting impact because of its widespread adoption by business schools. However, the financial crisis and recession (2007 to 2014) forced businesses to adjust rapidly and develop a 'new norm'. This norm is increasingly based on continual change, not the steady state that Porter assumed, making 'change' itself a significant factor in business strategy (McGrath, 2013).

Change continues to be disruptive, with volatility and uncertainty ensuring that there are only short periods of competitive advantage before change occurs. McGrath (2013) suggests that Porter's concept has evolved into transient competitive advantage. Disruption itself can create new business areas, blue oceans, where business has a sustained competitive advantage for a longer period than in existing markets (Kim \& Maugborgne, 2015).

A fundamental aspect of Porter's approach is that business has to manage its individual operational elements to improve margins. Resources can be physical assets or less tangible concepts, such as knowledge, and can be leveraged to build an advantage and with it 'strategic intent' (Hamel \& Prahalad, 1989). CRE is real estate "that house(s) the productive or business activities of an organisation" (CoreNet Global, 2015, p1), as such it is a physical asset of the firm, supporting the main business objectives but incidental to them. The way that it is acquired and managed is part of the firms' knowledge pool, which can provide a benefit that is difficult to replicate, and thus, in itself, is a competitive advantage 
(Park \& Glascock, 2010). CRE is generally of secondary importance within an organisation to its 'people' and provides a supporting role to them. Accordingly, CRE managers face various issues and have to make trade-offs that impact their decisions on CRE issues.

A significant focus of CRE research has been the development of CRE models. However, none of the papers consider how the CRE portfolio adjusts relative to change of the organisation, its financial performance or business strategy. Papers that consider CRE and its management use measures that are narrow tactical definitions (e.g. reduce costs) rather than broader strategic performance ones. Van Ree (2002) created definitions that link CRE with the business overall and have been adopted in this paper as they will resonate with business decision-makers as well as CRE managers. The objective of this research is to look at the extent of adjustment and adaption of the CRE portfolio to changes in turnover, profitability and employee numbers during a recession. That process of CRE realignment needs to be dynamic and continual, not a one-off event. The authors have defined the process as dynamic alignment of CRE. This is a knowledge gap that is addressed in this paper.

Longitudinal CRE research has been limited. Studies have focussed on stock market performance as the relative balance of owned to leased CRE has changed. Rodriguez \& Sirmans (1996) found that CRE could have a positive impact on stock market perception under various scenarios and more recent studies (e.g. Lasfer, 2007; Liow, 2004) have had similar outcomes. However, these studies do not consider the financial performance of a business and the impact on its CRE flexibility. Rather they consider financial performance through stock market returns, in particular how changes to the owned:leased ratio has affected investor sentiment. Longitudinal studies on how companies have translated significant change in their business environment into CRE flexibility and decision-making do not appear to have been carried out.

This study examines financial and CRE data collated from the financial accounts of companies in the FTSE350 over eight years during a period of significant change. Using a distributed time lag auto-regression model evidence has been sought of the relationship between financial performance and CRE flexibility to provide evidence of the link of $d y n a m i c$ alignment of CRE (or the lack thereof) to the business strategy. Three hypotheses are tested to seek to establish how CRE was realigned.

The remainder of the paper starts with a Literature Review, which considers changes to business strategy and its influence on CRE, especially CRE performance measurement. Next, the development of the hypotheses is outlined through sub-hypotheses and is followed by the methodology adopted. Finally, the results and their discussion are followed by a conclusion that considers the implications for academics and practitioners and suggestions for further work.

\section{Literature Review}

Business strategy is not a homogenous subject but has a wide range of different approaches (Mintzberg et al, 2009). One of the most influential concepts has been that of sustained competitive advantage (Porter, 1985), and its development, the Resource-based View (RBV) (Barney, 1991). A business manages its value chain, comprising both primary activities (operations, logistics, marketing, etc.) and support activities (infrastructure, HR, etc.) to improve the profit margin and increase the competitive advantage. Managers have to focus on efficiency and effectiveness of the individual elements to drive the profit margin. However, the business environment has evolved, it now only offers a transient competitive advantage (McGrath, 2013) resulting from change and innovation, leading to different approaches such as blue ocean strategy (Kim \& Maugborgne, 2015).

Flexibility of CRE is essential to operate within a business environment that offers transient competitive advantage and/or to allow a firm to be empowered to consider blue ocean strategies. Even if the strategic approach remains as sustained competitive advantage, "firms wishing to obtain above-normal returns must have better foresight than rivals" (Kunc \& Morecroft, 2010, p1166). Grantham et al (2007) argued that the organisational view of space has changed from a focus on place to one on work itself. Consequently, there is a need for less but more efficient superior quality space. Dispensing with CRE altogether is generally not a realistic option, but corporate agility needs to be matched by CRE agility. CRE managers need the ability to dynamically realign their CRE portfolio in response to planned and unforeseen changes, dynamic alignment.

Business strategy develops and evolves over time. The influence of internal and external factors results in strategy development and its implementation not being a controlled deliberate process, but rather an emergent complex iterative process (Mintzberg \& Water, 1985). Decision-making should improve over time providing closer alignment of CRE to operational needs, as well as other parts of the business, and therefore dynamic alignment of CRE should be evident.

However, the lack of attention by corporate strategic management researchers on CRE issues, (identified by Roulac, 2001) remains pertinent today (Heywood \& Kenley, 2008). The linkage between business and CRE has been stated as being poor from both business strategy and CRE research perspectives. Heywood (2011) suggested that alignment models were too CRE focused whereas Stadlhofer suggested that in Europe, "CRE has almost entirely been seen as a 
cost factor" (Stadlhofer, 2010, p97). In conclusion, some CRE research appears too business focussed (Scheffer et al, 2006), other too CRE centric, but all indicate a poor link with business.

A body of CRE research has focussed on modelling the alignment of the CRE portfolio with business strategy (e.g. Nourse \& Roulac, 1993; De Jonge, 1996 (cited by Appel-Meulenbroek et al, 2010); Lindholm et al, 2006b). Despite the different categorisations of possible CRE strategies, many agree that the fundamental driver for business strategy is to 'maximise wealth of shareholders' (e.g. Gibler \& Lindholm, 2012). That may hold true for a number of organisations, but it is not a universal proposition. A more complex set of influences can operate during decision making processes, including the self-interest of managers and corporate social responsibility (Mintzberg et al, 2002).

Heywood \& Kenley (2008) considered how operational decisions could provide an advantage through functional strategies but recognised that they could generate contradictory effects. Heywood \& Arkesteijn (2017) examined 20 different CRE alignment models concluding that the theoretical base of the subject is disorganised. More importantly, CRE alignment is "pluralistic and complex, being several things simultaneously" (Heywood \& Arkesteijn, 2017, p155). In an earlier study, Heywood (2011) concluded that none of the existing (ten) models had all the necessary components. These various studies consider the model itself, not the dynamics that impact the CRE portfolio, and they illustrate how individual CRE tactical decisions can influence business performance. The primary flow of decision-making is one directional; business strategy directs CRE strategy, which steers CRE decisions, the effects of which flow back into various business metrics. For example, to reduce CRE costs leases will not be renewed leading to an increase in profits from lower expenditure. Those CRE models that have been developed have considered various aspects of CRE including the efficiency and effectiveness of the CRE Manager (e.g. Nourse \& Roulac, 1993); the alignment of CRE with business strategy (e.g. Lindholm et al, 2006b; Haynes, 2012; Heywood, 2011); the own versus lease decision (e.g. Tipping \& Bullard, 2007); company performance (e.g. Nappi-Choulet et al, 2009) and how CRE affects stock market performance (e.g. Lasfer, 2007).

Business decision-making is theoretically linked to business strategy, the latter provides the direction of travel for the company and decisions should support its objectives. Good decisions add value, whereas unrectified, bad decisions lose value. "Ultimately, a company's value is no more (and no less) than the sum of the decisions it makes and executes" (Blenko et al, 2010, p57). What is essential for managing resources is the measurement of the performance of the business, and its constituent parts (Neely \& Bourne, 2000; Neely, 2005; Tangen, 2005). The measurement systems used need to be defined and explained and related to what their intention is, the improvement of the performance (Tangen, 2005).

Van Ree proposed that, "the profitability or performance of an organisation depends to a great extent on meeting the generic performance criteria" (Van Ree, 2002, p357). This generic framework provides a broader perspective than other models that have been developed and provides a link between business and CRE measures. These are:

- Effectiveness - the actual result achieved against the aimed for result:

- Efficiency - aimed for resource use against actual resourced used;

- Productivity - actual output to input;

- Flexibility - "the ability to recognise and adapt to changing circumstances" (Van Ree, 2002, p359).

These measures are qualitative and quantitative and business will need to choose which element has priority at a specific time. Ultimately though there will be a balance reflecting short and long-term goals of the business. Subsequent researchers have sought to develop the concept and have additionally suggested sustainability (Riratanaphong \& van der Voordt, 2015) and IT (Stegerean \& Gavrea, 2009). Others have structured a model along the lines of the Balanced Scorecard (Kaplan \& Norton, 1996) for example Lindholm et al (2006b) who produced narrower tactical definitions.

Cost reduction is often regarded as the default strategy for CRE (Gibson \& Lizieri, 2001), as "reducing cost in any area has a direct and immediate impact on the financial performance of the firm" (Lindholm et al, 2006a, p468). Cost reduction looks at efficiency only, the lowest input for a given output, it does not provide a wider perspective. On the other hand, effectiveness and productivity require consideration of both outputs and inputs together with their relative change. If demand falls the output needs to be adjusted downwards to reflect it, reducing the inputs required. The challenge of the 'CRE input' is that it can be relatively fixed. Declining output cannot be matched by an immediate reduction in the $\mathrm{CRE}$ input, which will have a negative effect on effectiveness, efficiency and productivity measures until the dynamic alignment process is completed.

Today's more fluid business environment requires rapid adjustment in a short period of time to make a contribution to strategy. The ability to change the dynamic tension between short time horizons (which require agility) and long-term strategic commitments (such as CRE) is now a required competency (Doz \& Kosenen, 2008). Change and disruption require frequent re-calibration to re-align the business and maintain transient competitive advantage (McGrath, 2013), namely being lean and mean. Similarly, MacIntosh \& MacLean (2015) stressed the requirement for double-loop learning (an emergent process) and continual adjustment.

Consequently, a fixed CRE portfolio is an impediment to business change and, therefore, its performance. Joroff \& Becker (2017) identified the move to an agile portfolio as one of six primary shifts in CRE over the last twenty-five 
years. The move from static to agile portfolios reflects that "agility has become an overreaching objective" (Joroff \& Becker, 2017, p33). Adaptability that results from a flexible CRE portfolio allows a business to change strategy to deal with threats or exploit opportunities that arise, or to recalibrate its operations and costs to maintain its efficiency and effectiveness. This requires short term occupational arrangements (licences, short leases and frequent, unfettered break clauses) or ownership. Legal and financial flexibility are two separate influencers of dynamic alignment and need to be explicitly stated, not implicitly dealt with (Gibson, 2000).

There has been a long running debate within CRE as to what offers business the greater flexibility, leasing or owning. Gibson suggested that owning a property is the only way to get total control, as "a lease always has both contractual and financial constraints" (Gibson, 2000, p152). Apgar (2009) took the opposite view that business needs to be nimble, therefore, own less and lease more, provided flexibility is built into the lease. Both arguments have a measure of validity and are not mutually exclusive; a nimble organisation will seek the least burdensome option for their specific business. A detailed review of the advantages and disadvantages is provided by Haynes \& Nunnington (2010), who identified the importance of cultural, financial and business factors in the choice. The balance between owning and leasing has been discussed in a number of papers, but those studies have generally been from the perspective of total returns for shareholders (e.g. Lasfer, 2007). In practice, there is the reality of having to deal with the availability of supply, requirements for specialised facilities, the attitude of landlords, break clause restrictions, etc.

\section{Hypothesis Development}

If managers seek competitive advantage they should focus on effectiveness, efficiency, productivity and flexibility as readily ascertainable performance measures. They should recognise that the business, including its CRE, is a complex adaptive system (Reeves et al, 2016), which should be learning from past decisions. The outcome of that learning should be a more flexible CRE portfolio, capable of dynamic alignment to meet the future needs of business. Therefore, during any downturn in business performance the CRE portfolio should be capable of rapid adjustment, in particular, a reduction of capacity. A relatively short lease profile will provide inherent flexibility allowing change to be achieved without creating a surplus leasehold property.

As managers seek to extract more from the value chain they will seek to generate more from less. The CRE portfolio should reduce as a consequence of improvements in efficiency, effectiveness and productivity, assuming no external drivers of change (e.g. acquisitions, mergers, etc.). A business will seek to generate more turnover and profit from less space. Allied to that will be the decision on the split between owned and leased space, what is best for the business. Therefore, a flexible CRE portfolio capable of dynamic alignment is required.

The adjustment of CRE, including the balance between leased and owned CRE, to reflect business performance changes between 2007 to 2014 could indicate how CRE flexibility and its capacity for dynamic alignment operates in practice. This period is chosen for this study because during the eight years business was subject to the impact of a financial crisis followed by a recession and then recovery. The resulting turbulence and financial pressures meant that businesses had to react to the instability by changing their strategy. With the change(s) to business strategy there should have been a corresponding re-alignment of the CRE portfolio and evidence of dynamic alignment should be seen.

Three hypotheses have been identified to test for the existence of flexibility and capability for dynamic alignment, to allow the CRE to facilitate improved efficiency, effectiveness and productivity in the business.

Adopting the sustained competitive advantage approach (Porter, 1985) to strategy would assume that resources are worked harder to improve the value chain, therefore, over time, the business would get more from its CRE portfolio. From the perspective of transient competitive advantage (McGrath, 2013) the commitment to CRE would be kept short term because change occurs frequently.

Hypothesis 1: The length of commitment to CRE will reduce over time to reflect improved CRE flexibility and effectiveness of CRE use.

Shorter leases should provide the most flexible option for a business with low total commitment (Apgar, 2009). This hypothesis is operationalized in terms of three sub-hypotheses.

Hypothesis 1a: The length of lease terms $>5$ years will fall

Ownership provides a fixed cost (Apgar, 2009) and studies on the owned:leased ratio (e.g. Lasfer, 2007) indicate that owning CRE affects shareholder returns.

Hypothesis 1b: The ownership of CRE will fall over time

Different industries have different profiles of ownership and leasing. Therefore, a further indicator of CRE change is the total CRE commitment, and this would remove any bias on 'ownership' preference for a category. Reducing costs, in its broadest sense improves financial performance (Lindholm et al, 2006a).

Hypothesis 1c: The total commitment to CRE will fall over time 
The financial crisis and recession affected turnover, profits and profit margins, thereby impacting performance measures of efficiency, effectiveness and productivity. If there was a flexible CRE portfolio there should have been an appropriate response to reduce the total CRE commitment and allow a rebalancing of input costs to restore productivity measures, possibly with a time lag. Therefore, to maintain efficiency, effectiveness and productivity levels a business will look at revenue and profitability and adjust its $\mathrm{CRE}$, consequently the second hypothesis is:

Hypothesis 2: As turnover and profitability decline/increase a business will react by reducing/increasing the proportion of total costs committed to CRE.

Hypothesis 2a: The financial commitment to CRE will fall/increase as revenue and/or profits decline/increase

Hypothesis 2b: The financial commitment to CRE will fall/increase as the profit margin declines/increases

As a business adjusts to demand for its products or services it will change its various resource inputs, including the number of full time employees (FTE), which will affect its space requirement and producing a corresponding contraction or expansion in the CRE portfolio. That will allow the business to maintain levels of efficiency, effectiveness and productivity in its operations.

Hypothesis 3: As FTE numbers increase or decrease there will be a corresponding change to the CRE portfolio

Hypothesis 3a: CRE total costs will decline/increase as FTE numbers decline/increase

When revenue/profit contract there will be an FTE reduction leading to a decline in CRE needs. Leased space should be easier to reduce than owned space, therefore there should be an initial jump in the ratio of owned to lease space when FTE declines.

Hypothesis 3b: As FTE numbers decline/increase the ratio of owned to leased CRE costs will increase/decrease

As more output is being sought from less input to enhance productivity from increased efficiency, there should be a decline over time in the CRE costs relative to FTE numbers.

Hypothesis 3c: CRE lease costs will decline over time relative to FTE numbers

The next section explains how the data were gathered and analysed to test these hypotheses.

\section{Methodology}

This research examines the financial data of companies in the UK's FTSE350 Index, the largest companies by market capitalisation listed on the London Stock Exchange, for the period 2007 to 2014, the financial crisis, recession and postrecession period. Following an initial analysis those companies that did not have accounts for the entire research period together with those non-typical in their use of real estate were excluded. The latter includes investment funds (vehicles run by banks), property companies (whose raison d'être is ownership) and natural resource companies (who focus on working land to remove minerals, etc.), resulting in data for 230 companies.

The companies were grouped into four CRE categories - Services \& Technology Manufacturing, Miscellaneous and Retail. Information on CRE in the annual reports does not provide a breakdown of property types, therefore these categories will not be exclusively property type specific. For example, whilst the Services \& Technology category will primarily comprise offices, it will also include other property types (e.g. retail banking premises and data centres). The quality of the data on financial cost of CRE in UK quoted companies is very good as UK accounting is governed by the International Accounting Standards Board (IASB), and the standards they issue provide a benchmark for the quality of the data in the accounts of individual companies, providing robust and reliable information for investors. The lack of a breakdown between property types and omission of data such as floor areas is recognised as a limitation of the data.

The data was extracted from annual reports, which were downloaded from the individual company websites. The yearend figures comprised turnover, profit before interest \& tax, net book value (freehold and long leasehold), surplus property provision (SPP), operating lease costs and FTE's. The SPP is made by a company for leases of $>1$ year remaining that are no longer operational, in effect it is a capital sum set aside to pay for the liability (IAS37). Lease costs are split in the accounts between to those of $<1$ year, 2-5 years and $>5$ years.

Four calculations were undertaken on the extracted data to create additional variables:

- Total CRE costs - the summation of net book value and operating lease costs to give a view of the total commitment to CRE. The figure used in this paper reflects just the lease rent commitment and the net book value. It does not include other costs (e.g. service charge, property taxes, facilities costs) which are not stated in the annual reports. It is estimated that rent represents circa $35 \%$ of the total financial commitment for CRE (Cooke \& Appel-Meulenbroek, 2015);

- Owned:Leased Ratio - the net book value divided by the total CRE costs. It provides a view on the balance of owned and leased CRE;

- Lease length $>5$ years - an estimate of the lease term for leases $>5$ years to give an overview of the 
longevity of the leased portfolio. The calculation is the total cost for leases $>5$ years divided by the average annual rent. The latter is the sum of leases $<1$ year and 2-5 years, divided by 5 . For example, a rent of $£ 200 \mathrm{~m}$ with the average annual rent of $£ 49 \mathrm{~m}$ produces a figure of 4.08 as the average term $>5$ years, indicating a predicted term for longer leases of 9.08 years $(5+4.08)$;

- Profit Margin - profit expressed as a percentage of turnover.

Two analysis techniques were used. The first is a descriptive to put the dataset and categories into context including trends over the eight-year period. Mean values were calculated for business and CRE metrics being the category total divided by the number of companies.

The primary technique is a distributed time lag auto-regression model to determine trend lines and the effects the independent variables have on the dependent variable. The nature of both the acquisition and disposal processes for CRE results in a slow speed of change, which leads to a lag between the decision and its implementation. A one-year lag reflects change of performance over 12 to 24 months impacting the CRE portfolio. A two-year lag would, in part, be a de-facto sign there is a lack of dynamic alignment in the portfolio. Whilst a business will monitor its performance on a daily, weekly or monthly basis, its decision-makers will only react once a specific trend has clearly developed, at that point change to the CRE portfolio will commence. Therefore, a one-year lag for the independent variables in the regression analysis was adopted.

The regression models were estimated for each category and all companies combined. The independent variables include the previous year's value of the dependent variable (the auto-regressions term), together with dummy variables for each year of the data, where the first year is taken as the basis. The dummy variables capture any year-specific effects, whereas the regression constant and auto-regression term pick up the general trend. A number of models look at trendlines and only include as independent variables the auto-regression term and the dummy variables for the years. To establish whether the estimated value of the auto-regression coefficient in a trend-line reflects a fall or increase overall the predicted values have been computed using the regression model for the different categories against each year for Hypothesis 1.

Other models test the relationship between the dependent variable and the business metrics. In these models the business metric is included as an independent variable along with the auto-regression term and the dummy variables. A correlation test was undertaken to identify multicollinearity between variables before a regression analysis was run, with the correlation threshold set at 0.7 . Regressions were run for the individual variables against the dependent variable and the one with the highest $\mathrm{R}^{2}$ (Adjusted) was selected. A check was made on the VIF to confirm the previous process had dealt with all of the collinearity issues. Throughout we have identified significance in tables by $* \mathrm{p}<0.1,{ }^{* *} \mathrm{p}<0.05$ and $* * * \mathrm{p}<0.01$.

\section{Results - Descriptives}

A brief summary of the key financial and CRE data, represented as mean per company, is shown in Table 1 . The change in the key financial measures from 2007 to 2014 are shown in Figures 1 to 5, which have rebased the data to 2007 as 100 to show the relative change over the period.

Table 1. Mean values per company of some key variables (2014)

\begin{tabular}{|c|c|c|c|c|c|}
\hline MEASURE & VALUE & $\begin{array}{c}\text { CHANGE } \\
2007-2014 \\
\end{array}$ & MEASURE & VALUE & $\begin{array}{c}\text { CHANGE } \\
2007-2014 \\
\end{array}$ \\
\hline ALL COMPANIES & \multicolumn{5}{|c|}{230 Companies } \\
\hline Turnover & $£ 5,522 \mathrm{~m}$ & $47 \%$ & Freehold Value & $£ 797 \mathrm{~m}$ & $22 \%$ \\
\hline Profit & $£ 475 \mathrm{~m}$ & $-4 \%$ & SPP & $£ 17 \mathrm{~m}$ & $145 \%$ \\
\hline FTE's & 27,842 & $11 \%$ & Lease Total & $£ 544 \mathrm{~m}$ & $17 \%$ \\
\hline $\begin{array}{l}\text { SERVICES \& } \\
\text { TECHNOLOGY }\end{array}$ & \multicolumn{5}{|c|}{$\begin{array}{l}108 \text { Companies: Finance (39); Construction (15); Professional \& Support Services (29); } \\
\text { Technology, Media \& Telecommunications (25) }\end{array}$} \\
\hline Turnover & $£ 5,575 \mathrm{~m}$ & $34 \%$ & Freehold Value & $£ 177 \mathrm{~m}$ & $-4 \%$ \\
\hline Profit & $£ 486 \mathrm{~m}$ & $-12 \%$ & SPP & $£ 25 \mathrm{~m}$ & $150 \%$ \\
\hline FTE's & 30,944 & $11 \%$ & Lease Total & $£ 420 \mathrm{~m}$ & $4 \%$ \\
\hline MANUFACTURING & \multicolumn{5}{|c|}{54 Companies: Consumer Goods (15); Engineering (26); Industrials (13) } \\
\hline Turnover & $£ 3,730 \mathrm{~m}$ & $48 \%$ & Freehold Value & $£ 1,666 \mathrm{~m}$ & $28 \%$ \\
\hline Profit & $£ 514 \mathrm{~m}$ & $51 \%$ & SPP & $£ 3 \mathrm{~m}$ & $200 \%$ \\
\hline FTE's & 18,768 & $8 \%$ & Lease Total & $£ 189 \mathrm{~m}$ & $41 \%$ \\
\hline MISCELLANEOUS & \multicolumn{5}{|c|}{45 Companies: Health (12); Leisure (8); Transport (8); Utilities (7) } \\
\hline Turnover & $£ 6,579 \mathrm{~m}$ & $95 \%$ & Freehold Value & $£ 687 \mathrm{~m}$ & $9 \%$ \\
\hline
\end{tabular}




\begin{tabular}{|l|c|c|l|c|c|} 
Profit & $£ 465 \mathrm{~m}$ & $-28 \%$ & SPP & $£ 6 \mathrm{~m}$ & $133 \%$ \\
\hline FTE's & 22,755 & $13 \%$ & Lease Total & $£ 354 \mathrm{~m}$ & $18 \%$ \\
\hline RETAIL & 23 Companies \\
\hline Turnover & $£ 7,417 \mathrm{~m}$ & $36 \%$ & Freehold Value & $£ 1,888 \mathrm{~m}$ & $39 \%$ \\
\hline Profit & $£ 345 . \mathrm{m}$ & $-1 \%$ & SPP & $£ 40 \mathrm{~m}$ & $135 \%$ \\
\hline FTE's & 45,268 & $13 \%$ & Lease Total & $£ 2,330 \mathrm{~m}$ & $26 \%$ \\
\hline
\end{tabular}

Figure 1. Key Financial Measures for All Companies

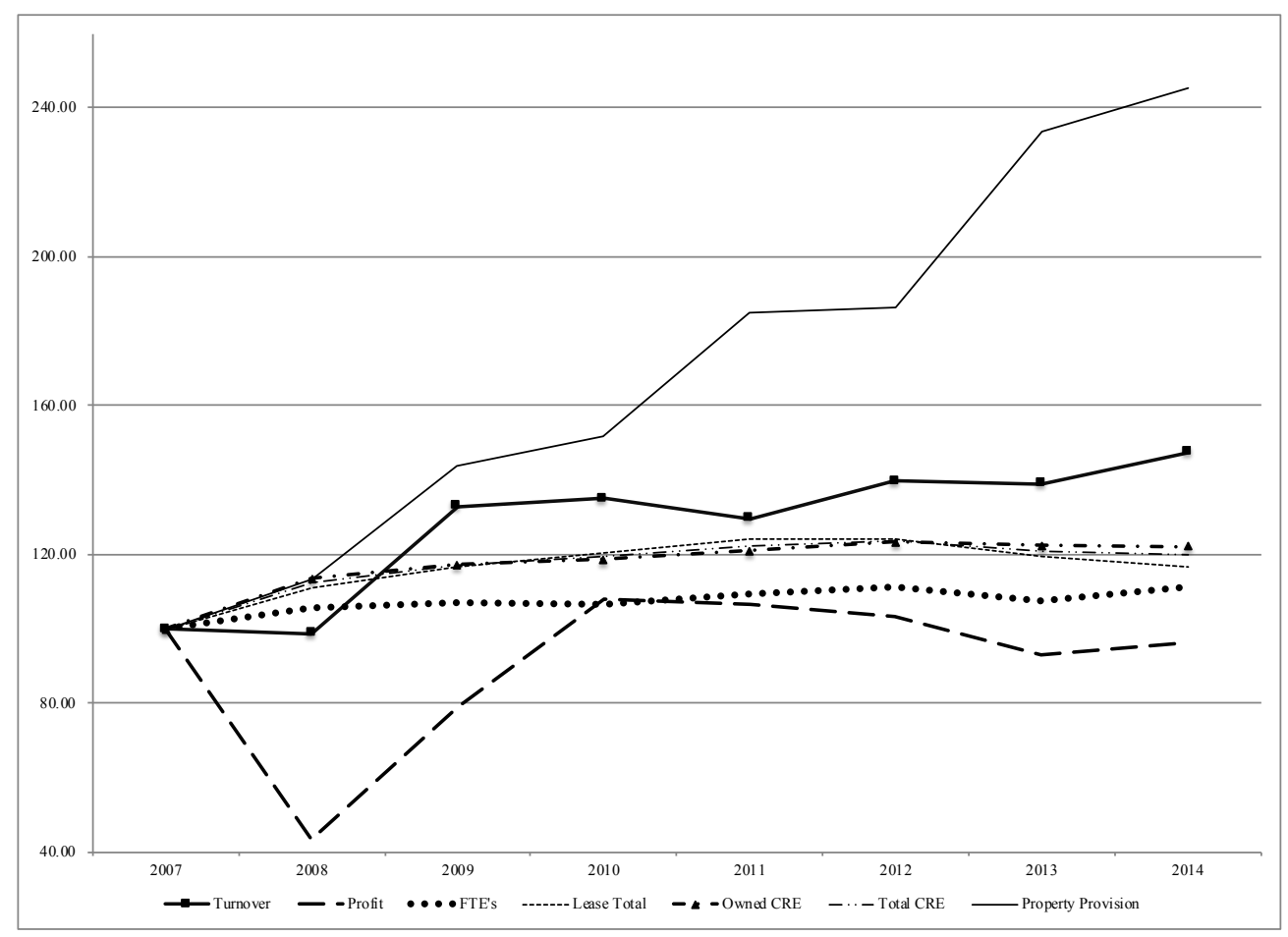

Figure 2 Key Financial Measures for Services \& Technology

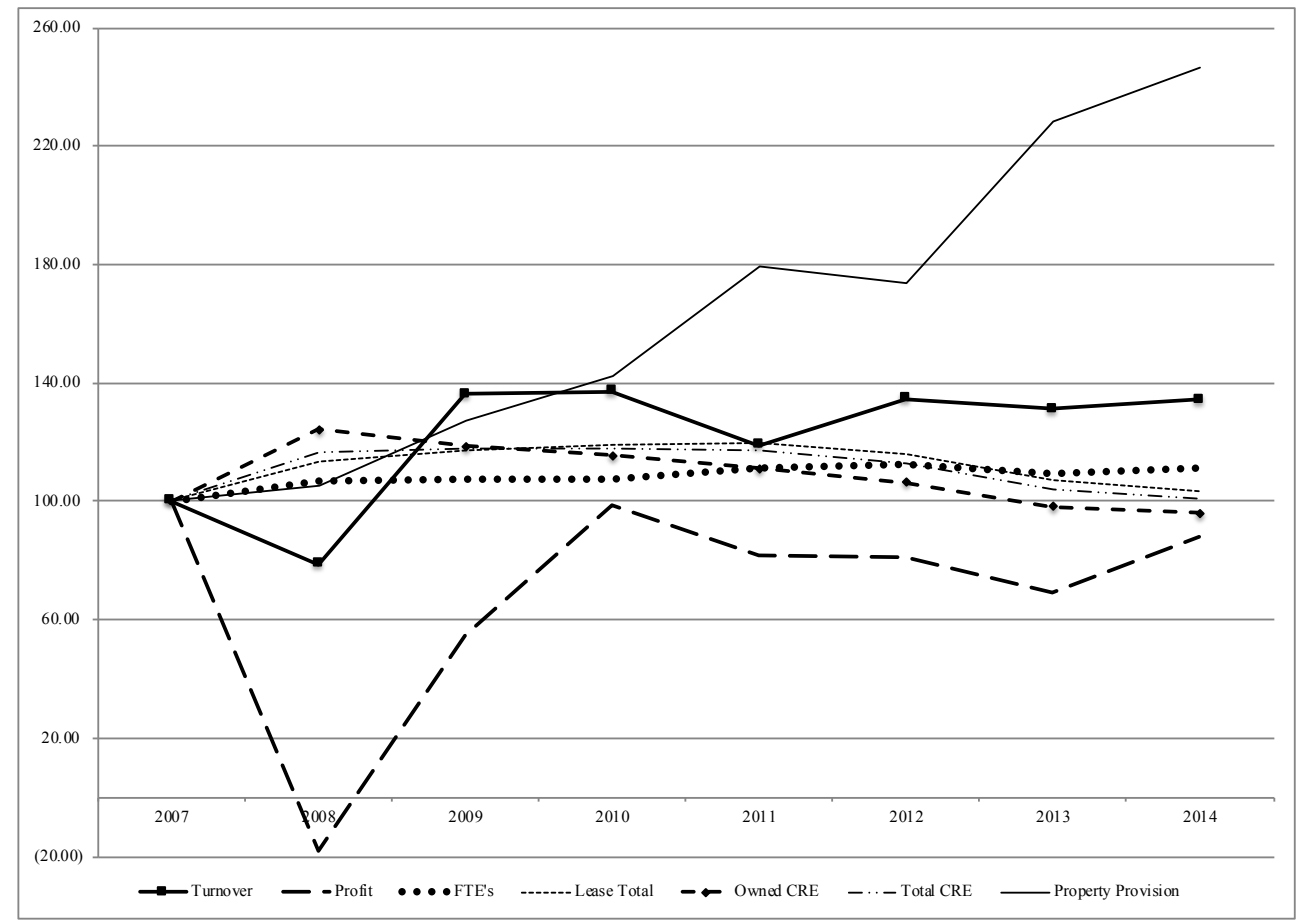

Figure 3 Key Financial Measures for Manufacturing 


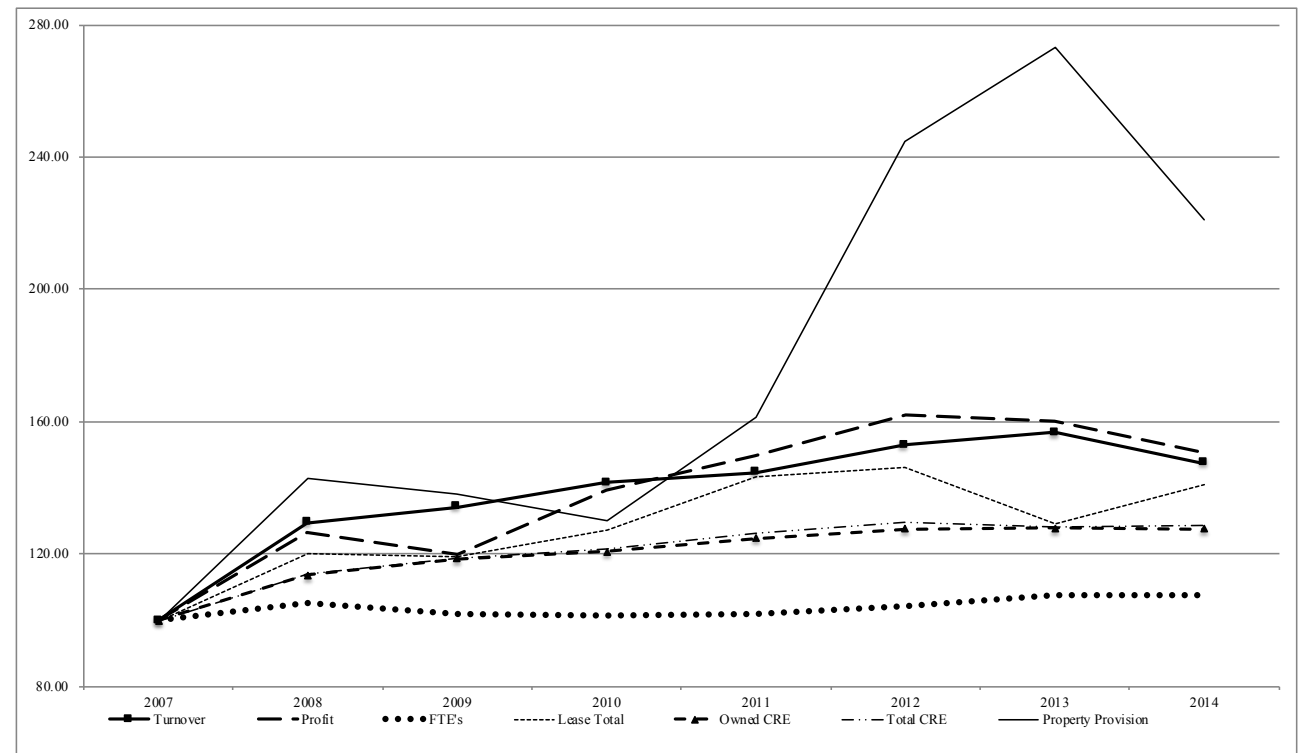

Figure 4 Key Financial Measures for Miscellaneous

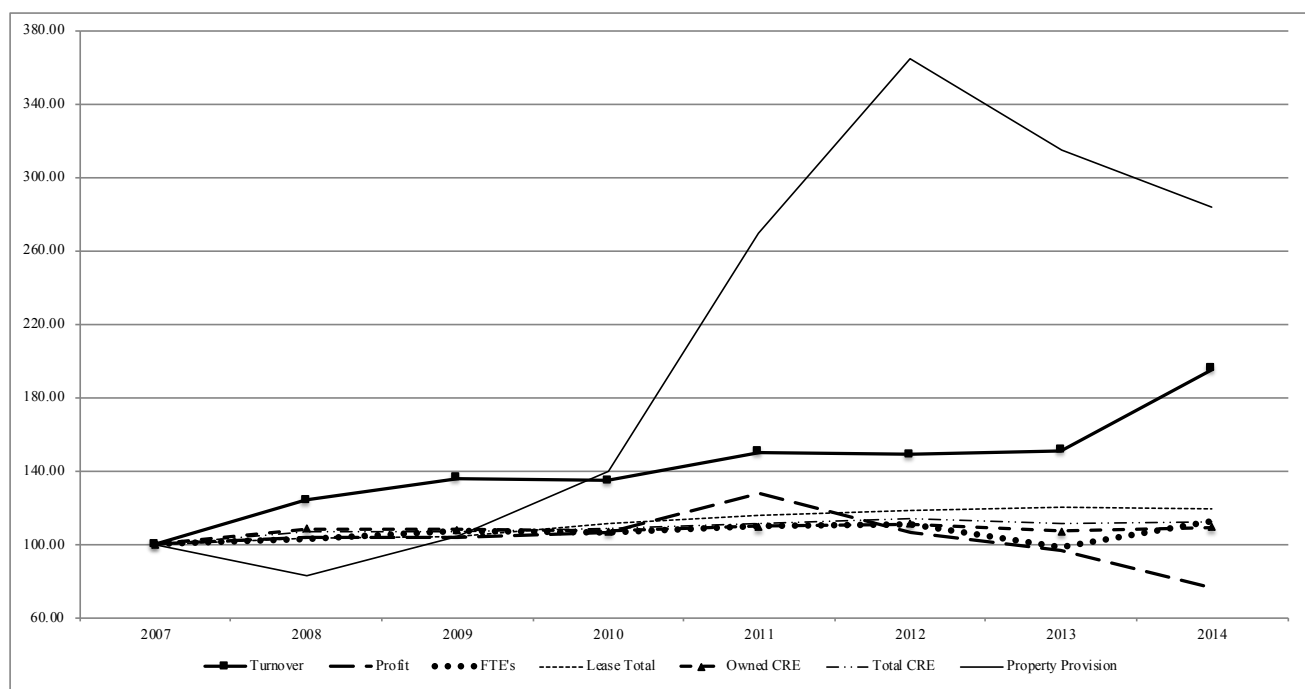

Figure 5 Key Financial Measures for Retail

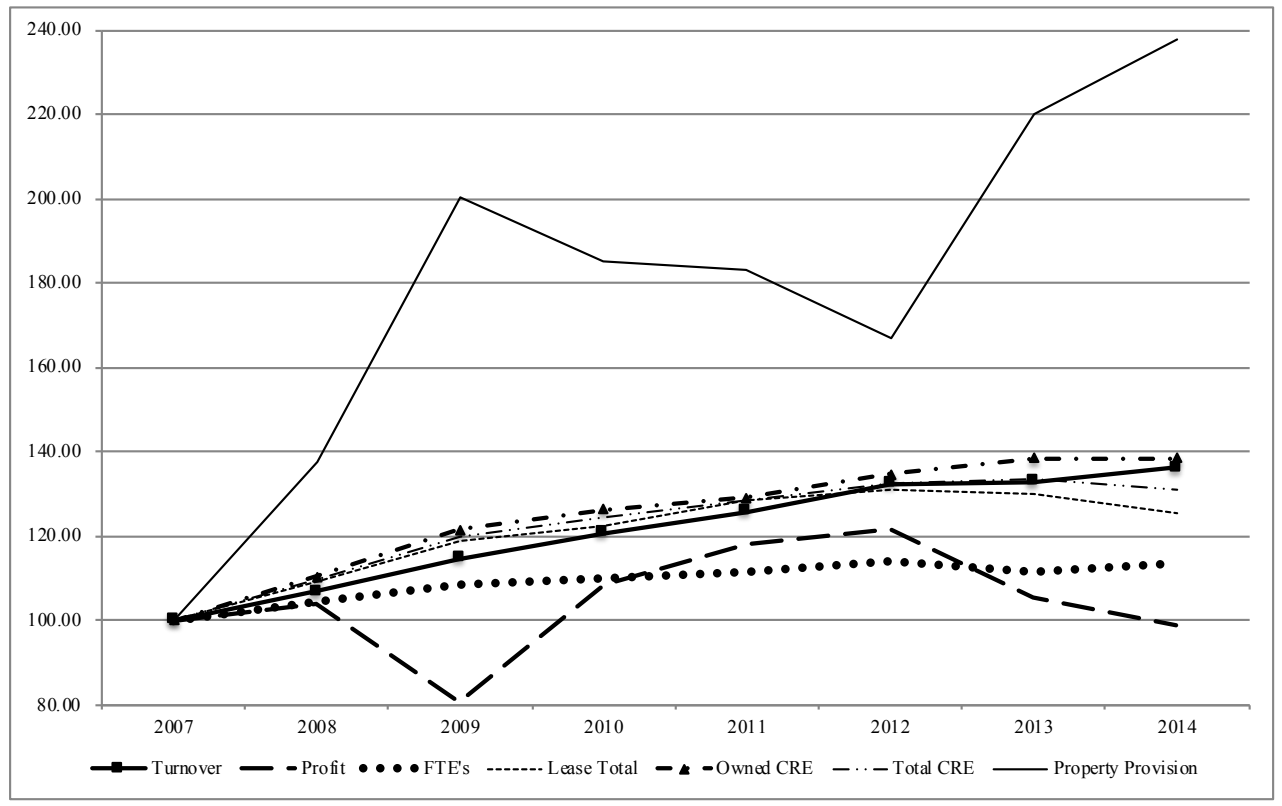


There has been a relatively muted change over the period for measures for All Companies (Figure 1) with two exceptions. Profits fell significantly in 2008, recovered by 2010 and have been relatively flat since ending 4\% below the 2007 level. Turnover has shown some variability over the period ending $45 \%$ higher than the start, but that rise has not been continual.

Figure 2 shows the measures for Services \& Technology with both turnover and profits relatively volatile. A significant change in 2008 saw turnover fall by $21 \%$ and profits by $118 \%$, creating losses. Turnover has recovered but profits struggled to regain the 2007 level ending 12\% below their 2007 level.

Manufacturing (Figure 3) has probably been the strongest category over the period with growth in turnover, rising $48 \%$, and profits, up 51\%. The mean SPP per Manufacturing company proportionately grew the most of all categories, although from a relatively small absolute figure.

Profits for the Miscellaneous category 2014 were 28\% below their 2007 level, in spite of a near doubling of turnover (Figure 4). This category had the largest percentage increase in SPP, although it fell from a peak in 2012.

The profits of retailers dropped in 2009 by 20\%, a year later than other categories (Figure 5). Profits rallied in 2011/ 2012 before declining to end 1\% below their 2007 level. In financial terms the SPP per retailer was $60 \%$ higher than the mean for the next highest category, Services \& Technology. The SPP profile showed unusual volatility between 2010 to 2012 .

\section{Results \& Discussion of Hypothesis Testing}

We will now turn to the stated hypotheses.

\section{Hypothesis 1}

A regression analysis tested Hypothesis $1 \mathrm{a}$, that the lease length $>5$ years was reducing over time. The purpose of the regression analysis here is to identify a trend, consequently no independent variables are included in the model other than the auto-regression term, the previous of the dependent variable, and the dummies for years. A regression model is estimated for each category and all companies. The results of the regression analysis are shown in Table 2.

Table 2. Results of trend-line regression analysis of long-term leases ( $>5$ years) (Hypothesis 1a)

\begin{tabular}{|c|c|c|c|c|c|c|c|c|}
\hline & Constant & $\begin{array}{l}\text { PY Average } \\
\text { Lease Term } \\
>5\end{array}$ & $\begin{array}{l}\text { Dummy } \\
2008\end{array}$ & $\begin{array}{c}\text { Dummy } \\
2009\end{array}$ & $\begin{array}{c}\text { Dummy } \\
2010\end{array}$ & $\begin{array}{c}\text { Dummy } \\
2011\end{array}$ & $\begin{array}{c}\text { Dummy } \\
2012\end{array}$ & $\begin{array}{c}\text { Dummy } \\
2013\end{array}$ \\
\hline \multicolumn{9}{|c|}{ ALL COMPANIES (R2 0.710; R2adj 0.709, P<0.01) } \\
\hline Estimate & 3.187 & $0.664 * * *$ & -0.692 & -0.533 & -0.324 & 0.115 & -0.234 & -0.137 \\
\hline t-value & 8.050 & 62.316 & -1.317 & -1.013 & -0.616 & 0.218 & -0.444 & -0.260 \\
\hline p-value & 0.000 & 0.000 & 0.188 & 0.311 & 0.538 & 0.827 & 0.657 & 0.795 \\
\hline \multicolumn{9}{|c|}{ SERVICES \& TECHNOLOGY (R2 0.681; R2adj 0.678, P<0.01) } \\
\hline Estimate & 2.942 & $0.683 * * *$ & -0.539 & -0.972 & -0.730 & -0.045 & -0.860 & -0.328 \\
\hline t-value & 5.465 & 39.532 & -0.766 & -1.381 & -1.035 & -0.064 & -1.219 & -0.464 \\
\hline $\mathrm{p}$-value & 0.000 & 0.000 & 0.444 & 0.168 & 0.301 & 0.949 & 0.223 & 0.643 \\
\hline \multicolumn{9}{|c|}{ MANUFACTURING (R2 0.837; R2adj 0.834, $\mathrm{P}<0.01$ ) } \\
\hline Estimate & -0.753 & $1.008 * * *$ & 0.354 & $1.059 * *$ & 0.626 & $0.999 * *$ & $1.033 * *$ & $0.890 * *$ \\
\hline t-value & -2.003 & 43.419 & 0.789 & 2.358 & 1.396 & 2.228 & 2.305 & 1.986 \\
\hline p-value & 0.046 & 0.000 & 0.430 & 0.019 & 0.164 & 0.026 & 0.022 & 0.048 \\
\hline \multicolumn{9}{|c|}{ MISCELLANEOUS (R2 0.776; R2adj 0.771, $\mathrm{P}<0.01$ ) } \\
\hline Estimate & 1.521 & $0.801 * * *$ & 0.938 & -0.292 & 0.893 & 0.934 & 1.070 & 0.326 \\
\hline t-value & 1.455 & 32.585 & 0.673 & -0.209 & 0.640 & 0.669 & 0.767 & 0.233 \\
\hline p-value & 0.147 & 0.000 & 0.502 & 0.834 & 0.523 & 0.504 & 0.444 & 0.816 \\
\hline \multicolumn{9}{|c|}{ RETAIL (R2 0.738; R2adj 0.726, P<0.01) } \\
\hline Estimate & 9.058 & $0.501 * * *$ & $-6.642 * * *$ & -3.236 & -3.565 & -3.397 & -3.756 & $-3.869 *$ \\
\hline t-value & 5.198 & 19.948 & -2.886 & -1.395 & -1.536 & -1.462 & -1.616 & -1.663 \\
\hline$p$-value & 0.000 & 0.000 & 0.004 & 0.165 & 0.127 & 0.146 & 0.108 & 0.098 \\
\hline
\end{tabular}

The predicted average lease term $>5$ years have been calculated for the period 2008 to 2014 (Figure 6).

Figure 6 Predicted values (years) of length of long-term commitment to CRE (Hypothesis 1a) 


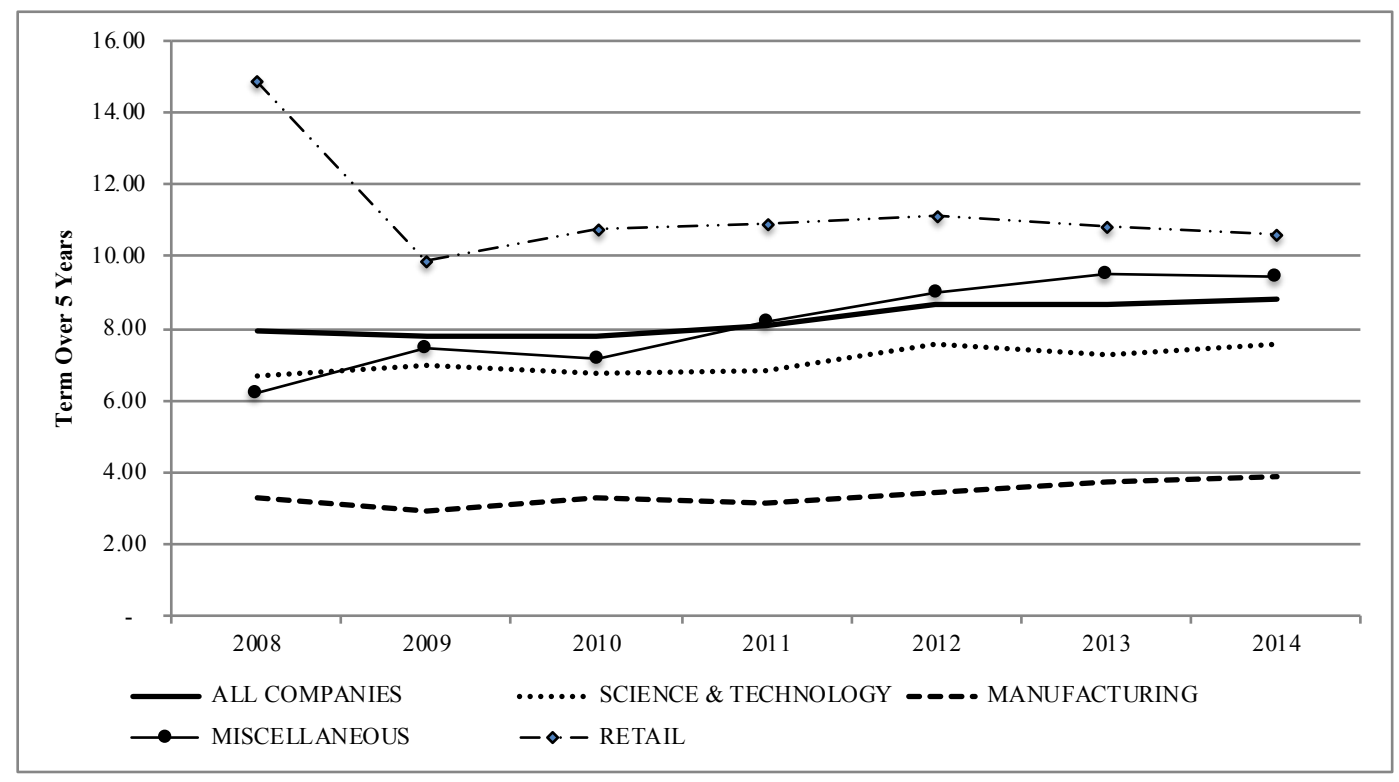

There is an overall upward trend in leases $>5$ years for four of the five categories (Figure 6). The exception is Retail with a significant drop in 2009 before being relatively flat for the remainder of the period. The dip coincides with the doubling of the SPP (see Figure 5). The fit of the data to the regression equation is relatively high ( $\mathrm{R}^{2}$ (Adjusted) is between 0.681 and 0.837 ). Hypothesis $1 \mathrm{a}$ is not supported because the length of leases $>5$ years has risen for all categories, excluding Retail.

The descriptive analysis shows an increase in ownership of CRE for all categories, except Services \& Technology ($4 \%$ ). To test Hypothesis $1 \mathrm{~b}$ trend-line regression models are estimated for the categories with total owned CRE as the dependent variable and previous year value of owned CRE and the dummies for the years as independent variables. The results are shown in Table 3.

Table 3. Results of trend-line regression analysis of Owned CRE (Hypothesis 1b)

\begin{tabular}{|c|c|c|c|c|c|c|c|c|}
\hline & Constant & PY Owned & $\begin{array}{c}\text { Dummy } \\
2008\end{array}$ & $\begin{array}{c}\text { Dummy } \\
2009\end{array}$ & $\begin{array}{c}\text { Dummy } \\
2010\end{array}$ & $\begin{array}{c}\text { Dummy } \\
2011\end{array}$ & $\begin{array}{c}\text { Dummy } \\
2012\end{array}$ & $\begin{array}{c}\text { Dummy } \\
2013\end{array}$ \\
\hline \multicolumn{9}{|c|}{ ALL COMPANIES (R2 0.992; R2adj 0.992, $\mathrm{P}<0.01$ ) } \\
\hline Estimate & 51.486 & $1.028 * * *$ & $-53.739 * * *$ & $-61.077 * * *$ & $-56.406 * * *$ & $-60.215 * * *$ & $-71.218 * * *$ & $-68.277 * * *$ \\
\hline t-value & 5.277 & 438.547 & -3.912 & -4.446 & -4.106 & -4.383 & -5.184 & -4.970 \\
\hline p-value & 0.000 & 0.000 & 0.000 & 0.000 & 0.000 & 0.000 & 0.000 & 0.000 \\
\hline \multicolumn{9}{|c|}{ SERVICES \& TECHNOLOGY (R2 0.970; R2adj 0.969, P<0.01) } \\
\hline Estimate & 49.545 & $0.973 * * *$ & $-53.687 * * *$ & $-49.425 * * *$ & $-51.865 * * *$ & $-53.061 * * *$ & $-58.867 * * *$ & $-49.192 * * *$ \\
\hline t-value & 4.865 & 154.345 & -3.752 & -3.454 & -3.625 & -3.709 & -4.115 & -3.438 \\
\hline p-value & 0.000 & 0.000 & 0.000 & 0.001 & 0.000 & 0.000 & 0.000 & 0.001 \\
\hline \multicolumn{9}{|c|}{ MANUFACTURING (R2 0.955; R2adj 0.954, $\mathrm{P}<0.01$ ) } \\
\hline Estimate & 69.675 & $1.016^{* * *}$ & $-69.308 * * *$ & $-70.531 * * *$ & $-53.459 * * *$ & $-75.066^{* * *}$ & $-71.316^{* * *}$ & $-90.866^{* * *}$ \\
\hline t-value & 4.849 & 88.487 & -3.452 & -3.513 & -2.662 & -3.736 & -3.549 & -4.522 \\
\hline p-value & 0.000 & 0.000 & 0.001 & 0.000 & 0.008 & 0.000 & 0.000 & 0.000 \\
\hline \multicolumn{9}{|c|}{ MISCELLANEOUS (R2 0.985; R2adj 0.985, P<0.01) } \\
\hline Estimate & 66.582 & $0.979 * * *$ & $-55.906 * *$ & $-57.590 * *$ & -33.598 & -43.688 & $-78.159 * * *$ & -37.706 \\
\hline t-value & 3.249 & 142.260 & -1.973 & -2.033 & -1.186 & -1.542 & -2.759 & -1.331 \\
\hline p-value & 0.001 & 0.000 & 0.049 & 0.043 & 0.237 & 0.124 & 0.006 & 0.184 \\
\hline \multicolumn{9}{|c|}{ RETAIL (R2 0.995; R2adj 0.995, P<0.01) } \\
\hline Estimate & 88.808 & $1.039 * * *$ & 4.155 & -87.590 & -119.073 & -81.124 & -107.625 & $-163.729 *$ \\
\hline t-value & 1.389 & 183.335 & 0.046 & -0.976 & -1.326 & -0.903 & -1.198 & -1.823 \\
\hline p-value & 0.167 & 0.000 & 0.963 & 0.331 & 0.187 & 0.368 & 0.233 & 0.070 \\
\hline
\end{tabular}

Figure 7 Predicted values (£m's) of ownership of CRE (Hypothesis 1b) 


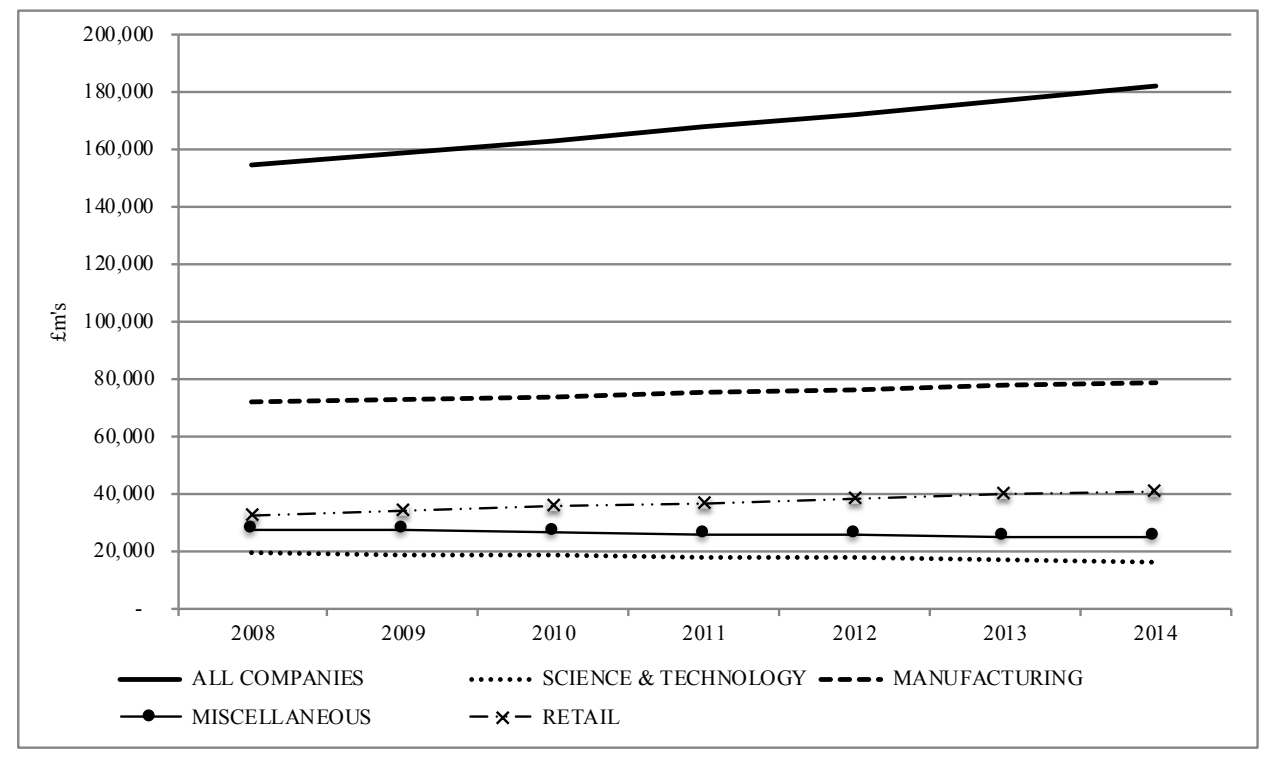

To evaluate the trend, predicted values for each year were calculated by the regression model for each year and each category (Figure 7). This identified that Services \& Technology and Miscellaneous categories had declined by $15 \%$ and $12 \%$ respectively, whilst for the other three categories ownership is increasing, with Retail highest $(+26 \%)$. The very high $\mathrm{R}^{2}$ (Adjusted) suggests a very good fit to the data. The analysis does not support Hypothesis $1 \mathrm{~b}$, ownership is increasing for three of the categories, not declining.

Total CRE costs continued to increase through the recession starting to fall from 2011 and 2012 . The descriptive analysis showed increases for all categories (Services \& Technology $+4 \%$; Manufacturing $+41 \%$; Miscellaneous $+19 \%$; Retail $+26 \%$ and All Companies $+17 \%$ ). To test Hypothesis 1c a trend-line regression analysis of total CRE costs was conducted using as independent variables the dummies for the years and the previous year's value of total CRE cost. The results are represented in Table 4.

Table 4. Results of trend-line regression analysis of Total CRE Cost (Hypothesis 1c)

\begin{tabular}{|c|c|c|c|c|c|c|c|c|}
\hline & Constant & $\begin{array}{c}\text { PY Total } \\
\text { CRE }\end{array}$ & $\begin{array}{c}\text { Dummy } \\
2008 \\
\end{array}$ & $\begin{array}{c}\text { Dummy } \\
2009\end{array}$ & $\begin{array}{c}\text { Dummy } \\
2010\end{array}$ & $\begin{array}{c}\text { Dummy } \\
2011\end{array}$ & $\begin{array}{c}\text { Dummy } \\
2012\end{array}$ & $\begin{array}{c}\text { Dummy } \\
2013\end{array}$ \\
\hline \multicolumn{9}{|c|}{ ALL COMPANIES (R2 0.990; R2adj 0.990, $\mathrm{P}<0.01$ ) } \\
\hline Estimate & 84.339 & $1.034 * * *$ & $-81.315^{* * *}$ & $-97.417 * * *$ & $-92.473 * * *$ & $-115.175 * * *$ & $-149.577 * * *$ & $-134.648^{* * *}$ \\
\hline t-value & 4.280 & 389.825 & -2.937 & -3.519 & -3.340 & -4.160 & -5.402 & -4.863 \\
\hline p-value & 0.000 & 0.000 & 0.003 & 0.000 & 0.001 & 0.000 & 0.000 & 0.000 \\
\hline \multicolumn{9}{|c|}{ SERVICES \& TECHNOLOGY (R2 0.997; R2adj 0.977, P<0.01) } \\
\hline Estimate & 112.956 & $0.976^{* * *}$ & $-90.335^{* * *}$ & $-94.742 * * *$ & $-103.304 * * *$ & $-120.385 * * *$ & $-147.802 * * *$ & $-117.210^{* * *}$ \\
\hline t-value & 4.796 & 177.546 & -2.738 & -2.871 & -3.131 & -3.648 & -4.479 & -3.552 \\
\hline p-value & 0.000 & 0.000 & 0.006 & 0.004 & 0.002 & 0.000 & 0.000 & 0.000 \\
\hline \multicolumn{9}{|c|}{ MANUFACTURING (R2 0.970; R2adj 0.969, $\mathrm{P}<0.01)$} \\
\hline Estimate & 89.441 & $1.032 * * *$ & $-100.166 * * *$ & $-88.539 * * *$ & $-61.431 * *$ & $-102.159 * * *$ & $-124.641 * * *$ & $-105.043^{* * *}$ \\
\hline t-value & 4.411 & 108.803 & -3.535 & -3.125 & -2.168 & -3.602 & -4.395 & -3.705 \\
\hline p-value & 0.000 & 0.000 & 0.000 & 0.002 & 0.031 & 0.000 & 0.000 & 0.000 \\
\hline \multicolumn{9}{|c|}{ MISCELLANEOUS (R2 0.981; R2adj 0.981, P<0.01) } \\
\hline Estimate & 70.893 & $0.993 * * *$ & -66.039 & -47.279 & -33.025 & -45.312 & $-86.557 * *$ & -51.330 \\
\hline t-value & 2.599 & 127.306 & -1.775 & -1.271 & -0.888 & -1.218 & -2.326 & -1.379 \\
\hline p-value & 0.010 & 0.000 & 0.077 & 0.205 & 0.375 & 0.224 & 0.021 & 0.169 \\
\hline \multicolumn{9}{|c|}{ RETAIL (R2 0.993; R2adj 0.992, P<0.01) } \\
\hline Estimate & 150.642 & $1.050 * * *$ & 3.115 & -204.918 & -207.129 & -235.706 & $-324.429 *$ & $-450.115 * *$ \\
\hline $\mathrm{t}$-value & 1.072 & 143.608 & 0.016 & -1.046 & -1.057 & -1.203 & -1.655 & -2.297 \\
\hline p-value & 0.285 & 0.000 & 0.987 & 0.297 & 0.292 & 0.231 & 0.100 & 0.023 \\
\hline
\end{tabular}

Figure 8 Predicted values (£m’s) of total CRE commitment (Hypothesis 1c) 


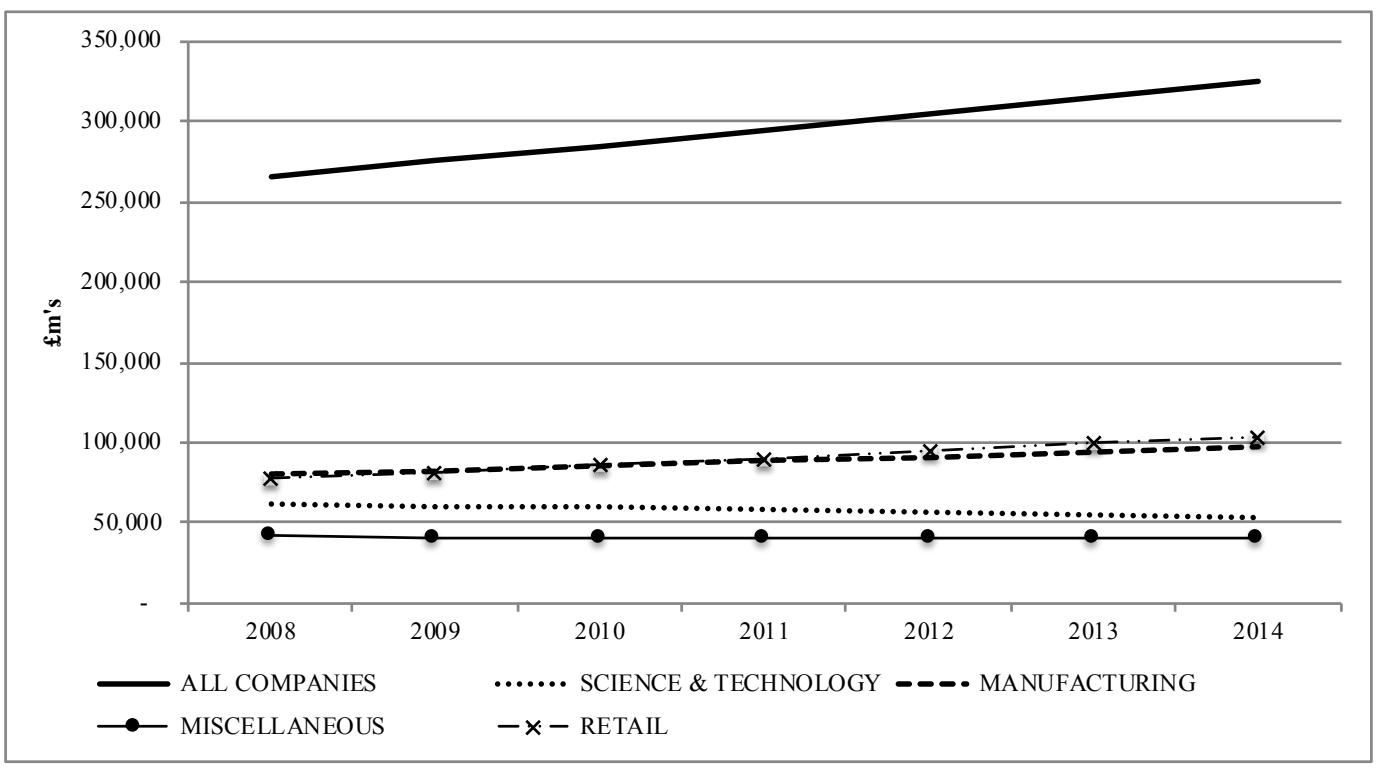

The predicted values from the equations are shown in Figure 8 the $\mathrm{R}^{2}$ (Adjusted) figure being close to 1.0, similar to Hypothesis $1 \mathrm{~b}$. The trend line for total costs of CRE generally indicates a steady rise over the eight years for Retail $(+33 \%)$, Manufacturing $(+21 \%)$ and All Companies (+22\%). In contrast, Services \& Technology and Miscellaneous both declined, falling $14 \%$ and $4 \%$ respectively. Hypothesis $1 \mathrm{c}$ is not supported as the total commitment to CRE is increasing for three of the five categories.

Consequently, Hypothesis 1 is not supported. Certain categories are seeing a decline in some CRE commitment measures but overall CRE commitment is not reducing over time. This suggests no improvement in flexibility nor in CRE effectiveness.

The increase in lease costs might not be the result of expansion of the amount of leased CRE held. The five-year upwards only rent review pattern in the UK could account for part or all of the change. In which case the increase in lease costs would be outside the control of the occupier. However, the combination of the significant increase in the SPP together with the increase in lease costs suggests restructuring of the portfolio might be occurring. The increase in lease cost probably reflects additional and/or better and/or more expensive space being taken to replace properties no longer appropriate for the business. The rise in the SPP indicates closing of properties before lease expiry.

A reduction in lease length would build flexibility into the leased portfolio, however this metric only declined for the Retail category and that was only a nominal fall. This suggests that any improved lease negotiating position for occupiers during the recession was short lived, post-recession landlords have returned to seeking longer leases.

The increase in CRE ownership could reflect the view that owning is better than leasing (Gibson, 2000). However, the change in the ownership balance may be a reflection of opportunism arising from the recession. The property investment market was depressed after the financial crisis and into the recession. Banks and lenders forced companies to sell properties to reduce debt. Banks themselves became forced sellers as a number of property companies became insolvent, therefore low prices offered opportunities for occupiers to purchase properties cheaply.

The analysis suggests that businesses have not achieved greater flexibility and/or improved effectiveness (getting more from less) in its CRE portfolio. This could indicate that CRE strategies are not just about cost reduction as suggested by some (e.g. Gibson \& Lizieri, 2001; Stadlhofer, 2010).

\section{Hypothesis 2}

This hypothesis examines the total commitment to CRE against the business metrics of profit, turnover and profit margin, all of which exhibited considerable variation over the eight years reflecting the impact of the financial crisis and recession. A positive relationship is hypothesized such that when turnover and/or profit and/or profit margin falls/rises the CRE commitment will decline/increase. Therefore, the hypothesis encompasses single metric or combinations of them.

The regression analyses of total CRE costs was carried out for Hypotheses 2a, 2b and 3a. It included the independent variables of turnover, profit, profit margin and FTE, together with their previous year figures, as well as the previous year total CRE cost (the auto-regression term) and dummies for the years. This approach allows us to control for FTE in evaluating the effects of financial performance variables (for Hypothesis 2) and, vice versa, to control for the financial performance variables in evaluating the effects of FTE. Ideally, we wanted to include all business metrics simultaneously, but because of multicollinearity we have not been able to do this. The procedure for selection of the best variable is explained in the methodology. The results showing the best metric based on fit are shown in Table 5 . 


\begin{tabular}{|c|c|c|c|c|c|c|c|c|c|c|c|c|c|c|}
\hline & Constant & $\begin{array}{c}\text { Total } \\
\text { CRE PY }\end{array}$ & Turnover & Profit & $\begin{array}{l}\text { Profit } \\
\text { PY }\end{array}$ & $\begin{array}{c}\text { Profit } \\
\text { Margin }\end{array}$ & $\begin{array}{c}\text { Profit } \\
\text { Margin } \\
\text { PY }\end{array}$ & FTE & $\begin{array}{c}\text { Dummy } \\
2008\end{array}$ & $\begin{array}{c}\text { Dummy } \\
2009\end{array}$ & $\begin{array}{c}\text { Dummy } \\
2010\end{array}$ & $\begin{array}{c}\text { Dummy } \\
2011\end{array}$ & $\begin{array}{c}\text { Dummy } \\
2012\end{array}$ & Dummy 2013 \\
\hline \multicolumn{15}{|c|}{ ALL COMPANIES (R2 0.990; R2adj 0.990, $\mathrm{P}<0.01$ ) } \\
\hline Estimate & 74.663 & $1.031 * * *$ & 0.000 & 0.005 & & -9.585 & $43.859 * *$ & $0.000^{* *}$ & $-82.188 * * *$ & $-96.331 * * *$ & $-92.838^{* * *}$ & $-115.271^{* * *}$ & $-149.649 * * *$ & $-134.580^{* * *}$ \\
\hline t-value & 3.655 & 298.151 & -0.281 & 0.917 & & -0.435 & 2.047 & 1.922 & -2.968 & -3.476 & -3.352 & -4.162 & -5.404 & -4.858 \\
\hline p-value & 0.000 & 0.000 & 0.778 & 0.359 & & 0.664 & 0.041 & 0.055 & 0.003 & 0.001 & 0.001 & 0.000 & 0.000 & 0.000 \\
\hline \multicolumn{15}{|c|}{ SERVICES \& TECHNOLOGY (R2 0.979; R2adj 0.979, $\mathrm{P}<0.01)$} \\
\hline Estimate & 95.512 & $0.951 * * *$ & $0.003 * * *$ & -0.004 & $0.030 * * *$ & -7.612 & 18.214 & 0.000 & $-76.392 * *$ & $-89.754 * * *$ & $-104.154 * * *$ & $-120.728^{* * *}$ & $-148.576^{* * *}$ & $-117.145^{* * *}$ \\
\hline t-value & 4.113 & 132.613 & 3.025 & -0.874 & 6.782 & -0.433 & 1.041 & 0.738 & -2.393 & -2.821 & -3.286 & -3.805 & -4.685 & -3.688 \\
\hline p-value & 0.000 & 0.000 & 0.003 & 0.382 & 0.000 & 0.665 & 0.298 & 0.461 & 0.017 & 0.005 & 0.001 & 0.000 & 0.000 & 0.000 \\
\hline \multicolumn{15}{|c|}{ MANUFACTURING (R2 0.970; R2adj 0.969, $<<0.01)$} \\
\hline Estimate & 88.193 & $1.049 * * *$ & & $-0.019^{*}$ & & 30.167 & & & $-101.890^{* * *}$ & $-89.800 * * *$ & $-62.631 * *$ & $-103.291 * * *$ & $-125.609^{* * *}$ & $-106.332 * * *$ \\
\hline t-value & 3.794 & 78.435 & & -1.894 & & 0.308 & & & -3.600 & -3.174 & -2.208 & -3.641 & -4.436 & -3.755 \\
\hline p-value & 0.000 & 0.000 & & 0.059 & & 0.758 & & & 0.000 & 0.002 & 0.028 & 0.000 & 0.000 & 0.000 \\
\hline \multicolumn{15}{|c|}{ MISCELLANEOUS (R2 0.982; R2adj 0.981, $\mathrm{P}<0.01$ ) } \\
\hline Estimate & 69.832 & $0.982 * * *$ & -0.001 & $0.027 * * *$ & & -47.412 & & 0.000 & $-66.251^{*}$ & -47.667 & -36.730 & -44.695 & $-84.097 *$ & -45.485 \\
\hline t-value & 2.258 & 110.014 & -0.422 & 2.603 & & -0.518 & & 0.398 & -1.799 & -1.296 & -0.997 & -1.215 & -2.281 & -1.226 \\
\hline p-value & 0.025 & 0.000 & 0.673 & 0.010 & & 0.605 & & 0.691 & 0.073 & 0.196 & 0.319 & 0.225 & 0.023 & 0.221 \\
\hline \multicolumn{15}{|c|}{ RETAIL (R2 0.995; R2adj 0.994, $\mathrm{P}<0.01)$} \\
\hline Estimate & -58.877 & $0.835^{* * *}$ & $0.129 * * *$ & & & $1,842.889 * *$ & & & 61.922 & -154.769 & -173.602 & -213.592 & -274.834 & $-410.765 * *$ \\
\hline t-value & -0.416 & 26.642 & 7.081 & & & 2.230 & & & 0.362 & -0.910 & -1.021 & -1.256 & -1.615 & -2.414 \\
\hline p-value & 0.678 & 0.000 & 0.000 & & & 0.027 & & & 0.718 & 0.364 & 0.309 & 0.211 & 0.108 & 0.017 \\
\hline
\end{tabular}


The regression for Hypothesis 2a identifies a significant positive relationship of total CRE cost with turnover for the Services \& Technology and Retail categories and with profit for Miscellaneous but a negative relationship for Manufacturing. A significant positive relationship exists for Services \& Technology between total CRE cost and the previous year profit, which corresponds to a negative relationship in the current year. Consequently, Hypothesis $2 \mathrm{a}$ is only supported for certain cases.

Hypothesis $2 \mathrm{~b}$ regression identified a significant positive relationship between total CRE costs and profit margin for the Retail category. The previous year profit margin is significant and positive for All Companies, corresponding to a negative relationship in the current year. Therefore, Hypothesis $2 \mathrm{~b}$ is only supported in certain cases.

A positive relationship between total CRE costs and turnover and/or profit and/or profit margin would indicate that CRE moves in line with business performance. Across all three metrics the relationships are not consistent with this hypothesis. The significant positive relationships that support the hypotheses are turnover for both Services \& Technology and Retail, profit for Miscellaneous and profit margin for Retail. Hypothesis 2 is supported for certain measures, indicating an element of dynamic alignment, but not a consistent one. This suggests that businesses have not created flexibility in their CRE to facilitate portfolio adjustment when financial performance necessitates cost reduction.

\section{Hypothesis 3}

Hypothesis 3 examines the commitment to CRE relative to FTE. The absolute change in CRE commitment per FTE varies across categories, a decline in Services \& Technology (-9\%), static in Miscellaneous (-0.6\%) and rising for All Companies $(+8 \%)$, Retail $(+16 \%)$ and Manufacturing $(+20 \%)$. CRE commitment per FTE also exhibits considerable variety, Services \& Technology is the lowest at $£ 19,289$, Miscellaneous ( $£ 45,741)$, All Companies (£48,032), Retail (£93,170) and Manufacturing (£98,754).

The results of the regression analysis for Hypothesis $3 \mathrm{a}$ for FTE in Table 5 indicates that FTE has a significant (positive) effect on total CRE costs for All Companies only. Hypothesis 3a is supported at the portfolio level only.

For this Hypothesis $3 \mathrm{~b}$ a regression analysis with the owned:leased ratio as the dependent variable was carried out with FTE as the independent variable. The results are shown in Table 6. FTE does not have a significant effect on the owned:leased ratio and Hypothesis $3 b$ is not supported.

Table 6. Results of regression analysis of Owned:Leased Ratio (Hypothesis 3b)

The regression analysis of total CRE lease costs was carried out for Hypothesis $3 \mathrm{c}$ with independent variables of the previous year's lease total, FTE, previous year FTE and dummies for the years. The results of the regression analysis are in Table 7.

Table 7. Results of regression analysis of Lease Total (Hypothesis 3c)

The regression analysis of FTE, as the independent variable, and lease total, the dependent variable, indicates a significant negative relationship for Manufacturing and a positive one for All Companies, Services \& Technology and Retail. Hypothesis $3 \mathrm{c}$ is not supported, lease costs are not declining against FTE over time, with the exception of the Manufacturing category. Hypothesis 3 is only supported in limited cases and lacks consistency across the sub-hypotheses.

Over the eight-year period there was not a decline in lease costs relative to FTE, with the exception of Manufacturing. In that category lease costs and FTE both increased, the latter at a quicker rate resulting in a small decline of lease costs per FTE. Elsewhere the increase in people appears to have been translated in to a requirement for more space with the growth in the CRE metrics higher than in FTE numbers. This could reflect more space per person and/or more expensive space being taken. A question to consider is whether the same pattern exists relative to floor space, which the financial accounts do not provide.

One aspect of the recession in the UK that drew considerable comment at the time was the relatively small decline in employment levels through the recession. Businesses appear to have retained employees rather than reduce numbers when turnover and/or profits fell. This has been cited as a reason for poor improvement in UK productivity post-recession (Guardian 2016). The lack of interaction between FTE numbers and CRE costs could suggest that business has been more focussed on the retention and development of talent compared to improving efficiency in their CRE portfolio. 


\section{Conclusion}

The period 2007-2014 was one of volatility for business in the UK. By 2014 revenue had grown by $45 \%$, but profitability remained below the 2007 level. Certain categories performed better than others, with Services \& Technology and Miscellaneous categories the poorest performers. Against that backdrop both CRE and surplus property commitments grew, SPP increasing by $145 \%$.

The findings suggest that businesses do not appear to have focussed on improving efficiency, effectiveness and productivity by working their CRE portfolio harder and using less space for more people. Rather they appear to have nurtured the workforce by improving the quality and/or quantity of CRE. In this study, we have focused on the actual relationship between various business (turnover, profit, profit margin and employee numbers) and CRE metrics (leases $>5$ years, ownership and total CRE costs). In particular, it has sought to identify evidence that businesses have incorporated dynamic alignment into their CRE. This would facilitate adjustment of CRE to changed operational requirements and improve efficiency, effectiveness and productivity measures. That evidence has not been found other than in limited cases.

The limited dynamic alignment capability identified by the study could reflect the inertia in the CRE portfolio, acting as a drag on change. Extensive change to an existing inflexible CRE portfolio will be expensive and disruptive, it needs to evolve rather than undergo an immediate radical change. Alternatively, this could be that CRE is not seen as anything other than a cost (as identified by Gibson \& Lizieri, 2001), therefore it does not receive adequate attention. This appears incompatible with the opinion that CRE is an asset of the business and CRE teams are moving from providing tactical to strategic advice (Joroff \& Becker, 2017). What this study does demonstrate is that cost reduction is not an apparent strategy. If it was there would be a significant reduction in the metrics of lease total, ownership cost and the total CRE commitment over the study period. Nor does the concept of agility appear to have become embedded in the mind-set of occupiers (Joroff \& Becker, 2017), otherwise there would have been a noticeable decline in lease length profiles.

The results showed evidence of dynamic alignment, but not in the way that theory suggested. The results suggest a more complex set of relationships rather than a simple cause and effect one, underpinning the view that a business (including its CRE) is a complex adaptive system (Reeves et al, 2016). What is apparent is that there has not been a significant adjustment to CRE strategy reflecting adoption of transient competitive advantage (McGrath, 2013) or blue ocean strategy (Kim \& Maugborgne, 2015). Even if the business strategy remains as sustained competitive advantage (Porter, 1985) it is essential to have a dynamic alignment capability for the CRE. It is possible that decision makers have not adapted to the changed business environment and adjusted their thought process commensurately. Understanding what decision-makers thoughts are in this respect would prove a useful study, both at the business level and for CRE. Alternatively, a more dynamic business strategy has been adopted, but dynamic alignment requirements has not been applied to CRE and its decision-making process. The theories of alignment of CRE to business strategy (e.g. Lindholm et al, 2006a) assumed a one-off not a continual process. That indicated a disconnect between the CRE and business strategy, this disconnect could be the reason for the omission of a dynamic alignment capability. What is required is continual adjustment of the CRE resulting in a complex iterative process that is emergent rather than deliberate single change.

This paper has sought to ascertain whether occupiers have built dynamic alignment capability into their CRE portfolio. The resultant flexibility enabling them to improve the efficiency, effectiveness and productivity of the portfolio and therefore the business itself. That agility would facilitate adjustment to future shocks to the organisation and from changes of business strategy. This research has identified mixed evidence of increased flexibility, but it is not a clear and unambiguous trend. Importantly it has closed a gap in the research by looking at what businesses actually did through a period of considerable change.

Several implications arise for those in practice from this study, in both business and CRE. The overarching point is how business and CRE inter-relate. In particular there is a need for a composite approach that builds dynamic alignment in to the CRE portfolio to avoid fettering the business in the medium to long term with unwanted CRE. The change to the accounting reporting standards that take affect $1^{\text {st }}$ January 2019 (IFRS16, 2016) may facilitate an improvement in future CRE agility. It will influence business and CRE metrics, consequently both business and CRE managers should be creating CRE flexibility ahead of their implementation. The bigger picture has to be a CRE portfolio that allows business to grasp transient opportunities and not be hampered by a fixed CRE profile and cost base.

\section{Limitations and recommendations for further research}

The effect of CRE slowing down change to strategy has been flagged for some time (e.g. Weatherhead, 1997). Further study is needed on why business has not built in flexibility to their CRE over the last 20 years generally, but in particular since the recession commenced in 2008. There is a need to identify and understand why building CRE dynamic alignment through flexibility has not become a priority in the decision-making process. The study of CRE in Australia by Willis (2008) offers a potential insight, in that 56\% of those dealing with CRE did not 
know what CRE flexibility was and $76 \%$ had CRE time horizons of $>5$ years. If a similar approach existed in the UK it could explain the lack of dynamic alignment capability.

Another influencing factor on the results found in this study could be the sample itself. These are quoted companies and generally long established consequently their ability to change direction may be limited in both extent and speed by factors such as management structure and providing shareholder returns. This study examines the net effects of decision-making, it does not look at the process itself. It is probable that changes to turnover, profit, profit margin and FTE will have been considered when CRE decisions were made. What is not known is the weighting applied to individual measures and knowledge of that is an important area for further research.

The results show that categories that are more narrowly defined by property type and/or business sector, such as Retail, appear to produce clearer result patterns than more diverse ones (e.g. Services \& Technology). The aggregation into larger categories may not have been beneficial in that context, therefore analysis at a more granular business sector level may improve clarity. The approach to decision-making may be more consistent within business sector rather than across property types. The downside of such an analysis could be small sample sizes, but nonetheless an exercise worth undertaking. A further line of research would be to extend the dataset forward into the post-recession period, a less volatile business environment, which may provide different insights into CRE adjustment.

Miscellaneous is a diverse category of both business sectors and property types. That might result in specific trends for business type being masked. For example, both Transport and Utilities are not typical CRE users, with large amounts of CRE relative to employees, as well as unusual property types, such as bus depots and reservoirs. Analysis by business sector should identify whether this is an issue and whether any should be treated as nontypical. A solution to some of these limitations would be to extend the sample size beyond the 230 companies in the FTSE350 and look at a greater variety of companies, not only those quoted but also those owned privately or through private equity vehicles, as well as those outside the UK.

Financial analysis provides one perspective of what has happened, which in itself is a limitation of the study. The data was drawn from published reports and those reports provide limited information. Ideally more specific detail of the CRE portfolio would help in the analysis.

The trend from the mid-1990's to 2003 of sale-and-leaseback's, especially in the UK, could be an explanation for the lack of flexibility. That process sought to release capital to support the core business and had the benefit that the total cost of the rent did not impact the balance sheet. That changes in January 2019 (IFRS16, 2016) when new accounting regulations will bring all leases on to the balance sheet. Whilst various studies (e.g. Rodriguez \& Sirmans, 1996) have identified the shorter-term benefits of sale-and-leasebacks, there do not appear to be any studies that look at the long-term effects. A comparison between those companies that undertook sale-andleasebacks and those who did not could be insightful. Which should include questioning whether the reduction in owned CRE and increase in long term lease commitment impacted CRE as a strategic long-term resource (Park \& Glascock, 2010).

The increase in CRE ownership could reflect an opportunistic approach during a depressed point in the property cycle. Understanding the perception of decision makers of the merits of lease versus own would be a beneficial study area, together with a trying to determine whether there is an ideal balance between owning and leasing. Previous work (e.g. Lasfer, 2007) did consider an element of this but carrying out a detailed investigation of what organisations did and why would provide useful for CRE researchers.

Various CRE alignment models (e.g. Gibler \& Lindholm, 2012) have held that the overriding objective of the business is to maximise shareholder wealth. The output of this study suggests that this does not necessarily hold true. It might be that the time horizon business decision-makers use is longer than the eight-year period of this survey. However, that would seem counter intuitive for quoted companies with performance announcements on a three-monthly cycle. Therefore, an implication of this study is that CRE alignment models need to question this underlying assumption and the one-off process of alignment. Further research should look at creating alignment models based on an iterative process and the theory of complex adaptive systems (Reeves et al, 2016). This study indicates that CRE remains inflexible with long time horizons and the move to agile portfolios (Joroff \& Becker, 2017) has not been achieved everywhere.

One aspect of the study has been to identify the significant increase in the SPP across the categories. The SPP may have been used as a mechanism to build 'flexibility' in to the leasehold portfolio. Understanding the relationships, if any, between business measures, CRE metrics and the SPP may cast light on this point.

Without a dynamic alignment CRE capability there is a risk of adverse effects on performance. There have been studies on business performance (e.g. Neely \& Bourne, 2000) and on CRE performance (e.g. Riratanaphong \& Van der Voordt, 2015) but there does not appear to have been a study that considers the impact of CRE on business performance measures and vice-versa. To conclude, there is still a lot more research necessary to support management in being able to truly provide CRE agility. 


\section{References}

Apgar, M. (2009). What Every Leader Should Know About Real Estate. Harvard Business Review November 2009, 100-107. Appel-Meulenbroek, R., Brown, M. G. \& Ramakers, Y. (2010). Strategic alignment of corporate real estate. In Proceedings of the 17th ERES Conference, 23rd-26th June, Milan, Italy.

Barney, J.B (1991). Firm Resources and Sustained Competitive Advantage. Journal of Management 17(1), 99-120.

Blenko, M.W., Mankins, M.C. \& Rogers, P. (2010). The Decision Driven Organisation. Harvard Business Review June 2010, 54-62.

Cooke, H. \& Appel-Meulenbroek, R. (2015). Impact of Corporate Real Estate on UK Business. In Proceedings of the 22nd ERES Conference, 24th-27th June, Istanbul, Turkey.

CoreNet Global (2015). The Essential Guide to Corporate Real Estate. Atlanta: CoreNet Global Inc.

Doz, Y. L., \& Kosonen, M. (2008). Creating and Testing Workplace Strategy. California Management Review (Spring 2008) 50(30), 95-118.

Gibler, K. M., \& Lindholm A-L. (2012). A test of corporate real estate strategies and operating decisions in support of core business strategies. Journal of Property Research 29(10), 25-48.

Gibson, V. (2000).Property Portfolio Dynamics: The Flexible Management of Inflexible Assets. Facilities 18(3), 150-154.

Gibson, V.A. \& Lizieri, C.M. (2001). Friction and Inertia: Business change, CRE Portfolios and the UK Office Market. Journal of Real Estate Research 22(1/2), 59-79.

Grantham, C., Ware, J.P. \& Williamson, C. (2007). Corporate Agility: A Revolutionary New Model for Competing in a Flat World. New York: AMACOM.

Guardian (2016). UK productivity gap widens to worst level since records began 18 February 2016. Retrieved from https://www.theguardian.com/business/2016/feb/18/uk-productivity-gap-widens-to-worst-level-since-records-began on 9th January 2018

Hamel, G. \& Prahalad, C.K. (1989). Strategic Intent. Boston: Harvard Business Review.

Haynes, B. and Nunnington, N. (2010). Corporate Real Estate Asset Management: Strategy and Implementation. Oxford: EG Books.

Haynes, B.P (2012). Corporate Real Estate Asset Management: Aligned Vision. Journal of Corporate Real Estate 14(4), 244254.

Heywood C. \& Kenley R. (2008). The sustainable competitive advantage model for corporate real estate. Journal of Corporate Real Estate 10(2), 85-109.

Heywood, C. (2011). Approaches to aligning corporate real estate and organisational strategy. In Proceedings of the 18th ERES Conference, 15-18th June, Eindhoven, The Netherlands.

Heywood, C. \& Arkesteijn, M. (2017). Alignment and theory in Corporate Real Estate alignment models. International Journal of Strategic Property Management 22(20), 144-158.

IAS37 (2001). International Accounting Standard 37: Provisions, Contingent Liabilities and Contingent Assets. London: International Accounting Standards Board.

IFRS16 (2016). International Financial Reporting Standard 16 Leases. London: International Accounting Standards Board.

Joroff, M. \& Becker, F. (2017). Exploiting change and uncertainty to drive corporate value. The Leader March 2017: 32-35.

Kaplan, R.S. \& Norton, D.P. (1996). The Balanced Scorecard. Boston: Harvard Business School Press.

Kim, W.C. \&Maugborgne, R. (2015). Blue Ocean Strategy (Expanded Edition). Boston: Harvard Business School.

Kunc, M.H. \& Morecroft, J.D.W. (2010). Managerial Decision Making and Firm Performance under a Resource-Based Paradigm. Strategic Management Journal 31(11), 1164-1182.

Lasfer, M. (2007). On the Financial Drivers and Implications of Leasing Real Estate Assets: The Donaldsons-Lasfer's Curve. Journal of Corporate Real Estate 9(2), 72-96.

Lindholm, A-L., Gibler, K.M. \& Levainen, K.I. (2006a). Modelling the Value-Adding Attributes of Real Estate to the Wealth Maximization of the Firm. Journal of Real Estate Research 28(4), 445-475.

Lindholm, A-L., Nenonen, S. \& Gibler, K.M. (2006b). A conceptual framework of CREM performance measurement tools. Journal of Corporate Real Estate 8.3: 108-119.

Liow, K.H. (2004). Corporate Real Estate and Stock Market Performance. The Journal of Real Estate Finance and Economics 29(1), 119-14.

Macintosh, R. \& Maclean, D. (2015). Strategic Management - Strategists at Work. London: Palgrave. 
McGrath, R.G. (2013). The End of Competitive Advantage. Boston: Harvard Business Review Press.

Mintzberg, H. \& Water, J.A. (1985). Of Strategies, Deliberate and Emergent. Strategic Management Journal 6(3), $257-272$.

Mintzberg, H., Simons, R. \& Basu, K. (2002). Beyond Selfishness, MIT Sloan Management Review Fall 2002 44(1), 67-74.

Mintzberg, H., Ahlstrand, B. \&Lampel, J. (2009). Strategy Safari (Second Edition) Harlow: FT Prentice Hall.

Nappi-Choulet, N. Missonier-Piera, F. \& Cancel, M. (2009). Value creation and the impact of Corporate Real Estate Assets. Journal of Corporate Real Estate 11(2), 78-90.

Neely, A. \& Bourne M. (2000). Why measurement initiatives fail. Measuring Business Excellence 4(4), 3-7.

Neely, A. (2005). The evolution of performance measurement research. International Journal of Operations \& Production Management 25(12), 1264-1277.

Nourse, H.O. \& Roulac, S.E. (1993). Linking Real Estate Decisions to Corporate Strategy. Journal of Real Estate Research $8(4), 475-494$.

Park, A. \& Glascock, J. (2010). Corporate Real Estate and Sustainable Competitive Advantage. Journal of Real Estate Literature 18(1), 1-19.

Porter, M.E. (1985). Competitive Advantage. New York: Free Press (Extended Edition in 1998 of the 1985 Original).

Reeves, M, Levin, S \& Ueda, D. (2016). The Biology of Corporate Survival. Harvard Business Review Jan-Feb 2016: 47-55.

Riratanaphong, C. \& Van der Voordt, T. (2015). Measuring the added value of workplace change. Facilities 33(11/12), 773792.

Rodriguez, M. \& Sirmans, C. (1996). Managing Corporate Real Estate: Evidence from the Capital Markets. Journal of Real Estate Literature 4(1), 13-33.

Roulac, S.E. (2001). Corporate Property Strategy is Integral to Corporate Business Strategy. Journal of Real Estate Research 22(1/2), 129-151.

Scheffer, J.J.L, Singer, B.P. \& Meerwijk, M.C.C Van (2006). Enhancing the contribution of corporate real estate to corporate strategy. Journal of Corporate Real Estate 8(4), 188-197.

Stadlhofer, G (2010). Corporate real estate performance: Contribution to core business competitiveness at global pharmaceutical enterprises. Journal of Corporate Real Estate 12(2), 96-116.

Stegerean, R. \& Gavrea, C. (2009). The Past and Present of Performance Measurement. In Managerial Challenges of the Contemporary Society Proceedings: 274-278. Babes Bolyai University, Cluj-Napoca, Romania.

Tangen, S. (2005). Demystifying productivity and performance. International Journal of Productivity \& Performance Management 54(1/2), 34-46.

Tipping, M. \& Bullard, R.K. (2007). Sale and Leaseback as a British Real Estate Model. Journal of Corporate Real Estate 9(40), 205-217.

Van Ree, H. J. (2002). The added value of office accommodation to organisational performance. Work Study 51(7), 357-363.

Weatherhead, M. (1997). Real Estate in Corporate Strategy. Basingstoke: Macmillan Press Ltd.

Willis, P. (2008). Corporate Real Estate Practice in Australia. Journal of Corporate Real Estate 10(1), 40-53. 